\title{
Az élettartammal és az időskori betegségteherrel kapcsolatos szubjektív várakozások
}

\author{
Zrubka Zsombor dr. ${ }^{1,2}$ - Kincses Áron ${ }^{3,4}$ - Gulácsi László dr. ${ }^{1,2}$ \\ Kovács Levente ${ }^{5}$ - Péntek Márta dr. ${ }^{1}$ \\ $\begin{array}{r}\text { 'Óbudai Egyetem, Egyetemi Kutatási és Innovációs Központ, Egészségügyi Közgazdaságtan Kutatóközpont, } \\ \text { Budapest }\end{array}$
${ }^{2}$ Budapesti Corvinus Egyetem, Corvinus Institute for Advanced Studies, Budapest
${ }^{3}$ Központi Statisztikai Hivatal, Budapest
${ }^{4}$ Miskolci Egyetem, Világ- és Regionális Gazdaságtan Intézet, Miskolc
}

Bevezetés: A lakosság idősödésével növekvő betegségteher egyéni és társadalmi szinten is fokozódó nyomást jelent. Célkitüzés: Felmérni a hazai általános felnőtt lakosságnak a korlátozottsággal, a gondozási igényekkel és a munkavégzéssel kapcsolatos időskori szubjektív várakozásait.

Módszer: Online keresztmetszeti felmérést végeztünk. A korlátozottsággal kapcsolatos várakozásokat a hivatalos szakstatisztikákban alkalmazott globális tevékenységkorlátozottsági mutató (Global Activity Limitation Indicator, GALI) segítségével elsőként vizsgáltuk. A jelen és szubjektíve várt munkavégzést, gondozási igényt, gondozói tevékenységet, valamint a jelen egészségi állapotot és szociodemográfiai helyzetet vizsgáló kérdéseket is feltettünk.

Statisztikai analizis: A mintában mért adatokat lokális polinom segítségével simítottuk, és a 60/70/80/90 éves korra adott szubjektív várakozásokkal hasonlítottuk össze. A szubjektív várakozásokat meghatározó tényezőket intervallumregresszióval becsültük.

Eredmények: 1000 kitöltőtől 914 érvényes választ kaptunk. Az átlagéletkor ( \pm szórás) 51,2 ( $\pm 15,2)$ év, a minta $55,8 \%$-a nő volt. A férfiak között a fizetett munkát végzők $(\mathrm{p}<0,001)$, a nók között az informális gondozók aránya volt magasabb $(\mathrm{p}=0,010)$. Az átlagos ( \pm szórás) szubjektíve várható élettartam $(81,0 \pm 11,1$ év) a minta statisztikailag várható élettartamánál $(79,6 \pm 3,7$ év) 1,3 évvel volt hosszabb $(\mathrm{p}<0,001)$, azonban az átlagos, szubjektíve várható egészséges élettartam $(64,6 \pm 15,2$ év) 5,3 évvel volt rövidebb a statisztikailag várható értéknél $(70,0 \pm 4,2$ év; $\mathrm{p}<0,001)$. A szubjektíve várható egészséges élettartamot és gondozási igényt elsősorban a válaszadók jelenlegi egészségi állapota befolyásolta. Az életmód és a szubjektíve várható egészséges élettartam között nőknél nem találtunk összefüggés, míg a túlzott gyakorisággal alkoholt fogyasztó vagy elhízott férfiak hosszabb egészséges élettartamra számítottak. A szubjektív várakozások meghatározó tényezői jelentős nemi különbségeket mutattak.

Következtetés: Az egészséggel, munkával és gondozással kapcsolatos szubjektív várakozások eltérőek a populációban mért valós adatoktól, és különböznek a nemek között.

Orv Hetil. 2021; 162(23): 911-923.

Kulcsszavak: szubjektív várakozások, szubjektíve várható egészséges élettartam, GALI, Európai Minimum Egészségmodul, informális gondozás, idősödés

\section{Subjective expectations concerning life expectancy and age-related health burden}

Introduction: The growing disease burden due to ageing populations poses a challenge on both individuals and societies.

Objective: To explore the general population's subjective expectations concerning disability, care needs and employment at older ages.

Method: We conducted an online cross-sectional survey. We were the first to measure subjective health expectations using the Global Activity Limitation Indicator (GALI) of official health statistics. Respondents' actual status and subjective expectations concerning employment, care needs and informal caregiver status, self-perceived health and sociodemographic factors were queried. 
Statistical analysis: We estimated sample characteristics by local polynomial smoothing and compared with subjective expectations at ages of 60/70/80/90 years. Determinants of subjective expectations were analyzed via interval regression.

Results: From 1000 subjects, 914 provided valid responses. Mean $( \pm$ SD) age was $51.2( \pm 15.2)$ years, and $55.8 \%$ of respondents were women. Paid employment was more frequent among men $(\mathrm{p}<0.001)$, while informal caregiver status among women $(\mathrm{p}=0.010)$. Mean $( \pm \mathrm{SD})$ subjective life expectancy $(81.0 \pm 11.1$ years $)$ was 1.3 years longer $(\mathrm{p}<0.001)$ than actuarial life-expectancy $(79.6 \pm 3.7$ years $)$, while mean subjective healthy life expectancy (sHLE) $(64.6 \pm 15.2$ years $)$ was 5.3 years shorter than actuarial healthy life expectancy $(70.0 \pm 4.2$ years; $p<0.001)$. sHLE and care needs were mainly determined by respondents' self-perceived health. Lifestyle risks were not associated with sHLE in women, while pervasive drinker or obese men expected longer healthy life span. Determinants of sHLE showed considerable gender differences.

Conclusion: Subjective expectations concerning health, employment and care needs differ from actual values of the general population, with considerable gender differences.

Keywords: subjective expectations, subjective healthy life expectancy, GALI, Minimum European Health Module, informal care, ageing

Zrubka Zs, Kincses Á, Gulácsi L, Kovács L, Péntek M. [Subjective expectations concerning life expectancy and agerelated health burden]. Orv Hetil. 2021; 162(23): 911-923.

(Beérkezett: 2020. november 7.; elfogadva: 2020. december 29.)

\begin{abstract}
Rövidítések
$\mathrm{CI}=($ confidence interval $)$ konfidenciaintervallum; EQ-5D = (EuroQoL 5-Dimension Questionnaire) 5 dimenziós Egészségi Állapot Kérdőív; FEKUTSTRAT = Felsőoktatás- és Kutatásstratégia; GALI $=($ Global Activity Limitation Indicator $)$ Globális Tevékenységkorlátozottsági Mutató; HLY = (healthy life years) egészséges élettartam; IQR = (interquartile range) interkvartilis tartomány; $\mathrm{MEHM}=($ Minimum European Health Module) Európai Minimum Egészségmodul; PROM = (patient-reported outcome measure) betegek beszámolóin alapuló kimenet; QALY = (quality-adjusted life year) minőséggel súlyozott életév; $\mathrm{SD}=$ standard deviáció
\end{abstract}

A várható élettartam növekedésével párhuzamosan a társadalom idősödése egyre növekvő demográfiai nyomást jelent az európai társadalmak nagy részére, beleértve hazánkat is [1]. Ugyan hazánkban az egészségben töltött élethossz növekedésének köszönhetően az egészségi problémából adódó korlátozottsággal töltött életévek száma 2009 és 2018 között 17,4 évről 15,1 évre csökkent [2], az öregségi nyugdíjkorhatár emelkedett [3], és a születési arányszám is javulást mutatott az elmúlt években [4], a születésszám csökkenésének következtében az időskorúak aránya növekszik a magyar lakosság körében $[5,6]$. Ezzel párhuzamosan az időskori függőségi ráta (a gazdaságilag nem aktív 14 év alatti és 65 év feletti lakosság aránya a potenciálisan aktív 15-64 éves népességhez viszonyítva) az elmúlt évtizedben jelentős mértékú növekedést mutatott [7]. Az életkor növekedésével várhatóan nőni fog a lakosság gondozás iránti igénye, ezáltal a keresőképes korban levő́k gazdasági terhei mellett várhatóan az egészségügyi és szociális rendszerre, valamint a családtagokra háruló gondozási feladatok is növekedni fognak [8-11]. Az idős, beteg hozzátartozó gondozása az informális gondozást (az egészségügyi ellátórendszer keretein kívül nyújtott, nem finanszírozott és általában nem professzionális ápolást) nyújtó családtagok életminőségét, általános egészségi állapotát és munkaképességét is jelentôsen befolyásolhatja $[9,12]$.

A jövőben felmerülő (krónikus) megbetegedések, idősödéssel kapcsolatos korlátozottságok nemcsak egyéni szinten okoznak majd jelentős terheket, hanem társadalmi szinten is komoly hatással bírnak [13, 14]. Az ellátások tervezéséhez szükség van az embereknek a jövőbeli egészségi állapotukkal, élethelyzetükkel kapcsolatos elgondolásainak ismeretére. A várható élettartammal kapcsolatos kutatások rávilágítottak arra, hogy az emberek szubjektív várakozásai a hivatalos demográfiai adatoktól eltérőek lehetnek, ami befolyásolhatja az egészséggel, életmóddal, fogyasztással, munkával és pénzügyekkel kapcsolatos döntéseiket [15-19]. A szubjektíve várható élettartam mellett a holland és a magyar lakosság körében végzett kutatások vizsgálták a lakosság, valamint a krónikus betegek életminőséggel kapcsolatos szubjektív várakozásait az EQ-5D-kérdő́iv segítségével [20-24]. Az EQ-5D-mércét a klinikai gyakorlatban és vizsgálatokban az egészséggel összefüggő életminőség mérésére, valamint egészséggazdaságtani elemzésekben a minőséggel súlyozott életévek (quality-adjusted life year, QALY) meghatározására alkalmazzák. Az EQ-5D az egészség öt dimenziójában (mozgékonyság, önellátás, szokásos tevékenységek, fájdalom/rossz közérzet és szorongás/depresszió) kérdez rá a pillanatnyi problémák súlyosságára. Az így leírt egészségi állapotokhoz a lakosság preferenciái alapján az életminőséget jellemző hasznossági értékek (EQ-5D-index) rendelhető́k, amelyeknél az 1 a teljes 
egészséget és a 0 a halált jelenti [25]. Az Európai Unió országaiban azonban a hivatalos várható egészséges élettartam (healthy life years, HLY) becslései a Globális Tevékenységkorlátozottsági Mutatóval (Global Activity Limitation Indicator, GALI) felvett adatokon alapulnak, amely mutató nem a pillanatnyi egészségi problémák súlyosságát, hanem az egészségi ok miatt (legalább hat hónapig) fennálló tartós korlátozottság mértékét jellemzi (lásd módszerek) [26-28]. Ugyan a lakosság pillanatnyi (GALI-) állapotát tükröző keresztmetszeti felmérések idősoros adatai rendelkezésre állnak, a lakosság korlátozottsággal, a gondozás iránti igényekkel, valamint a munkavállalással kapcsolatos szubjektív várakozásairól kevés ismerettel rendelkezünk.

Kutatásunk célja az átlaglakosság által az idősebb életkorokra $(60,70,80$ és 90) szubjektíve várt egészséggel kapcsolatos tartós korlátozottságok megismerése, valamint az azokat befolyásoló tényezők felderítése. Ezzel párhuzamosan vizsgáljuk az egészségügyi és szociális ellátásokkal és az informális gondozással kapcsolatos szubjektív várakozásokat. Eredményeinkkel hasznos információkkal kívánjuk segíteni az egészségügyi és a szociális ellátórendszer tervezését, finanszírozásuk kialakítását, prioritásaik megfogalmazását, a krónikus betegségek és az időskori állapotok kezelésére vonatkozó forrásallokációs és finanszírozási döntéseket.

\section{Módszerek}

\section{Adatgyüjtés}

Kérdőíves, internetalapú keresztmetszeti felmérést végeztünk a hazai általános lakosság körében $(\mathrm{n}=1000)$. A kérdőíves kutatást az Egészségügyi Tudományos Tanács - Tudományos és Kutatásetikai Bizottság hagyta jóvá (az etikai engedély száma: 5113-2/2018/EKU). A kérdőívet kitöltő személyek írásos beleegyezésüket adták a vizsgálathoz. A válaszadók toborzása, a kérdőív online felületre programozása és az adatfelvétel piackutató cég bevonásával történt. Az adatgyưjités a magyar lakosságra 65 éves korig bezárólag a fóbb demográfiai (nem, életkorcsoport, lakóhely és iskolázottsági szint) jellemzókre reprezentatív kvóták alapján történt. A kutatás fó eredményei már publikálásra kerültek [24], a jelen közlemény a korlátozottsággal, a foglalkoztatottsággal és a gondozási igényekkel kapcsolatos kérdéscsoportok részletes elemzését foglalja magában.

\section{A válaszadók jelen állapotának, foglalkoztatottságának és gondozási igényeinek felmérése}

Kutatásunkban a válaszadók jelen egészségi állapotát az Európai Minimum Egészségmodul (Minimum European Health Module, MEHM) segítségével vizsgáltuk [29, 30]. A MEHM a következő három kérdésből áll:
A) a jelen egészségérzet: „Milyen az Ön egészsége általában?” (nagyon jó / jó / kielégitó" / rossz / nagyon rossz); B) tartós betegség: „Van-e hosszan tartó betegsége vagy egészségi problémája?” (hosszan tartónak tekintünk egy betegséget, egészségi problémát, ha legalább 6 hónapja tart, vagy várhatóan legalább 6 hónapig fog tartani)" (van / nincs); C) Globális Tevékenységkorlátozottsági Mutató (GALI): „Korlátozza-e Önt valamilyen egészségi probléma legalább 6 hónapja a mindennapi tevékenységek elvégzésében?" (súlyosan korlátozza / korlátozza, de nem súlyosan / nem korlátozza).

Felmértük továbbá az igénybe vett fizetett ellátást és informális ellátást (a betegeknek, gondozásra szorulóknak az egészségügyi és szociális ellátás formális keretein kívüli, a társadalombiztosítás által nem térített gondozása) (van / nincs; heti óraszám) és a meg nem valósult gondozási igényt (van / nincs). Rákérdeztünk a válaszadó foglalkoztatottsági helyzetére (teljes vagy részállásban dolgozik / nem dolgozik), és hogy jelenleg vagy az elmúlt tíz évben betöltött-e legalább hat hétig tartó informális gondozói szerepet (igen / nem).

Háttérváltozóként a családi állapotra, az iskolai végzettségre, a munkaviszonyra, a lakóhelyre, a háztartás jellemzőire és a jövedelemre vonatkozó adatokat rögzítettünk, és 11 pontos numerikus skálával felmértük a válaszadók általános boldogságszintjét [31].

\section{A szubjektive várbató élettartam, az egészséges élettartam, a gondozási igények és a foglalkoztatottság becslése}

A válaszadók szubjektíve várható élettartamát a pontbecslés módszerével kérdeztük: „Véleménye szerint Ön hány éves koráig fog élni?" Csak a válaszadó életkora és 100 év közé eső értékeket fogadtuk el érvényes válasznak.

A jövőbeli állapotokkal kapcsolatos kérdéseket 60/70/80/90 éves életkorokra vonatkozóan tettük fel, és mindig csak a válaszadó koránál magasabb életkorokat jelenítettük meg. Az egészséggel kapcsolatos szubjektív várakozásokat a módosított GALI (a továbbiakban: GALI) segítségével mértük fel: „Mit gondol, idősebb korában korlátozza-e majd tartósan (legalább 6 hónapon át végig) valamilyen egészségi probléma a mindennapi tevékenységek elvégzésében, és ha igen, milyen mértékben?" 60/70/80/90 éves korban: nem korlátoz / korlátoz, de nem súlyosan / súlyosan korlátoz. A szubjektíve várható egészséges élettartam kiszámítása a hivatalos, egészségesen várható élettartam becslésének módszertanához hasonlóan a bármely mértékű (nem súlyos vagy súlyos) korlátozottság megléte alapján történt [32, 33]. Csak a szubjektíve várható élettartamnál fiatalabb életkorokra adott válaszokat vettük figyelembe.

A szubjektíve várható egészséges élettartam becslése során a válaszadó életkora, jelen korlátozottsága (GALI: nem korlátozott / korlátozott), a korlátozottság szubjektíve várt életkora (nincs adat / 60/70/80/90 éves) és a 
szubjektíve várható élettartam alapján számos eltérő esetet különböztettünk meg. A becsléshez a jelen vagy a szubjektíve várt legmagasabb korlátozottságtól mentes, illetve a legalacsonyabb korlátozottsággal bíró életkornak vagy a szubjektíve várható élettartamnak a középértékét használtuk a következő esetek kivételével: A) Ha a válaszadó jelenleg korlátozott és idősebb életkorokra is kizárólag korlátozott állapotokat várt, akkor a korlátozottság kezdetét múltbelinek tekintettük, és a jelen életkort -5,25 évre tettük. B) Inkonzisztensnek jelöltük és kizártuk azokat a válaszadókat, akik a jövőbeli életkorokra várt állapotok javulását feltételezték a kor előrehaladtával (például egy 55 éves válaszadó 60 és 70 éves korra korlátozottságot várt, majd 80 éves kortól korlátozottságtól mentes állapotot várt élete végéig). Ugyanakkor elfogadtuk, ha a válaszadó jelenleg korlátozottsággal él, de idősebb korára korlátozottság nélküli állapotot várt, feltételezve, hogy a válaszadó helyesen méri fel jelen korlátozottságának javulási esélyeit. A továbbiakban az egészséges és a nem korlátozott fogalmakat egymással felcserélhetó értelemben használjuk.

A válaszadók jövőbeli gondozási igényeivel kapcsolatos kérdéseink szintén a 60,70, 80 és 90 éves korra vonatkoztak. A válaszadókat megkértük, becsüljék meg, hogy heti hány óra gondozásra lesz szükségük (semennyi / $\geq 1$ óra), és milyen ellátási formát tudnak majd igénybe venni (saját otthonában önkéntes segitók - családtagok, barátok, ismerösök - segitik / családtaghoz költözik, és ott segitik / saját otthonában, saját maga által fizetett segito"t alkalmaz / olyan gondozóintézménybe költözik, amelyet az állam biztosit, és nem kerül pénzbe / olyan gondozóintézménybe költözik, amelyet maga választ, de amely jelentös havi költséggel jár / egyéb). Megkérdeztük továbbá, mit gondolnak, hány éves korukig fognak teljes vagy részmunkaidős fizetett munkát végezni, illetve akik már nem végeznek fizetett munkát, hány éves korban hagyták abba.

\section{Statisztikai elemzés}

A minta jellemzőit deskriptív módszerekkel elemeztük. $\mathrm{Az}$ átlagadatok mellett a szórást, medián adatok mellett az interkvartilis tartomány (interquartile range, IQR) alsó és felső határértékét adtuk meg. A szubjektíve várható életkort és a szubjektíve várható egészséges életkort a hazai lakosság 2019. évi, a hivatalos várható életkorra és a várható egészséges életkorra vonatkozó becsléseihez hasonlítottuk. A hivatalos várható egészséges életkorra vonatkozó becslések 5 éves korcsoportokra elérhetők, melyekból regressziós módszerrel koréves becsléseket készítettünk [34].

A statisztikai és a szubjektíve várt értékeket páros tpróbával hasonlítottuk össze. A kategorikus változók összefüggéseit kereszttáblamódszerrel és $\chi^{2}$ függetlenségi próbával vizsgáltuk. Tekintettel az egyes életkorokban a válaszadók számának és a pontbecslések értékeinek ingadozására, a szubjektíve várható egészséges élettartamot és a fizetett munkavégzés végét az egyes életkorokra lokális polinom simítással becsültük. A módszer minden egyes életkor \pm 5 éves tartomány átlagértékeit számítja, és a koronként kapott pontokat simított görbével köti össze. A 95\%-os megbízhatósági tartomány kiszámítása hasonlóképpen történt. A minta jellemzőit leíró bináris változók (például korlátozott / nem korlátozott) gyakoriságértékeit 10 éves korcsoportokra átlagoltuk, vagy az egyes életkorokra vonatkozó értékeket a 95\%-os konfidenciaintervallummal lokális polinom simítással számoltuk. Ezáltal a mintában mért értékek és a 60/70/80/90 éves korokra vonatkozó szubjektív várakozások (pontbecslések) egymással összehasonlíthatók. Az eredményeket elsősorban grafikusan ábrázoltuk; szignifikánsnak tekintettük, ha a szubjektíve várt átlagértékek a jelen értékek 95\%-os megbízhatósági tartományán kívül estek. A szubjektíve várható és a statisztikai élettartam és egészséges élettartam átlagértékeit páros t-próba, a medián értékeket előjelteszt segítségével hasonlítottuk össze.

A korlátozottság kezdetét (szubjektíve várható egészséges élettartam), a fizetett munkavégzés végét és a gondozási igény kezdetét meghatározó tényezőket intervallumregresszióval vizsgáltuk. Az intervallumregresszió a cenzorált lineáris regresszió speciális esete, amelynek során - amennyiben megmagyarázandó változó konkrét értékei nem ismertek - elegendő azokat a tartományokat megadni, ahová a magyarázandó érték esik. A megadott tartományok lehetnek zártak (az alsó és a felső érték is ismert), nyíltak (csak az alsó vagy a felső érték ismert), ismeretlenek vagy az ismert konkrét értékek. A magyarázó változók koefficiensei a lineáris regresszióhoz hasonlóan értelmezhetők. Esetünkben a magyarázó változó értékének egységnyi változása a szubjektíve várható élettartamot, a fizetett munkavégzés végét vagy a gondozási igény kezdetét jelző életkor változását mutatják években kifejezve. Az elemzéseket Stata 16 statisztikai programcsomaggal végeztük [35].

\section{Eredmények}

\section{A válaszadók jellemzôi $i$}

A kérdőívet 1000 válaszadó töltötte ki, közülük 914 egyén válaszai voltak érvényesek az előre meghatározott kritériumaink szerint. A minta tulajdonságait a hazai felnőtt lakosság szociodemográfiai jellemzői mellett az 1 . táblázatban foglaljuk össze. A továbbiakban az érvényes válaszadók adatait elemezzük. Az átlagéletkor $( \pm S D)$ 51,2 $( \pm 15,2)$ év volt. A minta tulajdonságai az online felmérésekre általában jellemző módon eltértek az átlaglakossági normáktól [36]: a legfiatalabb - 18-29 éves és a legidősebb - 70+ éves - korosztály alul-, míg a 6069 éves korosztály felülreprezentált volt, és az iskolázottság a magasabb végzettséggel rendelkezők felé tolódott. A férfiak és a nők között szignifikáns eltéréseket találtunk a fó demográfiai paraméterek tekintetében. A nők körében a férfiakhoz képest alacsonyabb volt az általános iskolát végzettek aránya (25,9\% vs. 33,9\%; 
1. táblázat | Demográfiai és egészségiállapot-jellemzók

\begin{tabular}{|c|c|c|c|c|c|c|}
\hline & & Konziszten & laszadó & A kérdőí & öltötte & Felnőtt lakosság $\geq 18^{a}$ \\
\hline & & $\mathrm{n}$ & $\%$ & $\mathrm{n}$ & $\%$ & $\%$ \\
\hline Összes & & 914 & 100 & 1000 & 100 & 100 \\
\hline Nem & Férfi & 404 & 44,2 & 455 & 45,5 & 47,1 \\
\hline & Nő & 510 & 55,8 & 545 & 54,5 & 52,9 \\
\hline Korcsoport & 18-29 év & 85 & 9,3 & 101 & 10,1 & 17,2 \\
\hline & 30-39 év & 146 & 16,0 & 156 & 15,6 & 16,0 \\
\hline & 40-49 év & 179 & 19,6 & 201 & 20,1 & 19,6 \\
\hline & 50-59 év & 150 & 16,4 & 165 & 16,5 & 15,1 \\
\hline & 60-69 év & 261 & 28,6 & 275 & 27,5 & 16,3 \\
\hline & $\geq 70$ év & 93 & 10,2 & 102 & 10,2 & 15,8 \\
\hline Iskolai végzettség & Általános iskola & 269 & 29,4 & 300 & 30,0 & 45,4 \\
\hline & Középiskola érettségivel & 393 & 43,0 & 422 & 42,2 & 33,3 \\
\hline & Egyetem / föiskola & 252 & 27,6 & 278 & 27,8 & 21,2 \\
\hline Lakóhely & Fôváros & 199 & 21,8 & 223 & 22,3 & 18,3 \\
\hline & Megyeszékhely & 202 & 22,1 & 222 & 22,2 & $52,4^{*}$ \\
\hline & Egyéb város & 282 & 30,9 & 301 & 30,1 & - \\
\hline & Község & 231 & 25,3 & 254 & 25,4 & 29,3 \\
\hline Régió & Közép-Magyarország & 309 & 33,8 & 338 & 33,8 & 31,0 \\
\hline & Dunántúl & 258 & 28,2 & 280 & 28,0 & 30,2 \\
\hline & Alföld és Észak & 347 & 38,0 & 382 & 38,2 & 38,9 \\
\hline Egy före jutó & Első ötöd (Q1) & 184 & 20,1 & 206 & 20,6 & 15,8 \\
\hline háztartási jövedelem & Második ötöd (Q2) & 143 & 15,7 & 149 & 14,9 & 20,1 \\
\hline & Harmadik ötöd (Q3) & 82 & 9,0 & 94 & 9,4 & 23,9 \\
\hline & Negyedik ötöd (Q4) & 108 & 11,8 & 120 & 12,0 & 21,7 \\
\hline & Ötödik ötöd (Q5) & 240 & 26,3 & 258 & 25,8 & 18,5 \\
\hline & Hiányzik & 157 & 17,2 & 173 & 17,3 & - \\
\hline Felnőttek a háztartásban & Egy & 258 & 28,2 & & & \\
\hline & Kettő & 421 & 46,1 & & & \\
\hline & $>2$ & 235 & 25,7 & & & \\
\hline Gyermek a háztartásban & Nincs & 698 & 76,4 & & & \\
\hline & Egy & 129 & 14,1 & & & \\
\hline & $>1$ & 87 & 9,5 & & & \\
\hline Foglalkoztatottság & Fizetett munkát végez & 463 & 50,7 & & & \\
\hline & Nem végez fizetett munkát & 451 & 49,3 & & & \\
\hline Családi állapot & Házas / élettársi kapcsolat & 553 & 60,5 & & & \\
\hline & Egyéb & 361 & 39,5 & & & \\
\hline Gondozás & Nincs segítő, és nincs szüksége rá & 812 & 88,8 & & & \\
\hline & Van segítő & 75 & 8,2 & & & \\
\hline & Nincs segítő, de szüksége lenne rá & 27 & 3,0 & & & \\
\hline Boldogság & Átlag (SD) & $6,8(2,3)$ & & & & \\
\hline Jelen egészségérzet & Nagyon jó & 98 & 10,7 & & & \\
\hline & Jó & 421 & 46,1 & & & \\
\hline & Elfogadható & 306 & 33,5 & & & \\
\hline & Rossz & 79 & 8,6 & & & \\
\hline & Nagyon rossz & 10 & 1,1 & & & \\
\hline GALI & Nem korlátozott & 577 & 63,1 & & & \\
\hline & Korlátozott, de nem súlyosan & 293 & 32,1 & & & \\
\hline & Súlyosan korlátozott & 44 & 4,8 & & & \\
\hline Hosszan tartó betegség & Nincs & 342 & 41,1 & & & \\
\hline & Van & 491 & 58,9 & & & \\
\hline
\end{tabular}

${ }^{a}$ Demográfiai évkönyv, 2019 (KSH), az életkor, a nem és az iskolai végzettség eloszlását a $\geq 18$ korcsoportra, a lakóhelyet és régiót a teljes hazai lakosságra vonatkozóan adjuk meg.

*Megyeszékhely és egyéb város együttesen.

GALI = Globális Tevékenységkorlátozottsági Mutató; KSH = Központi Statisztikai Hivatal 
$\mathrm{p}=0,017)$, az Alföld és Észak régióból származók aránya $(32,8 \%$ vs. $44,6 \% ; \mathrm{p}=0,001)$, és magasabb a 40 év alatti válaszadók aránya $(32,0 \%$ vs. $16,8 \% ; \mathrm{p}<0,001)$. Összességében a válaszadók 36,9\%-a számolt be korlátozottságról, 11,2\% a gondozás iránti kielégített vagy nem kielégített igényről, 43,2\% egészségi állapota volt elfogadható / rossz / nagyon rossz, és 58,9\% említett hoszszan tartó betegséget. A válaszadók 39,6\%-a volt informális gondozó a vizsgálat pillanatában vagy az azt megelőző 10 év során.

\section{Szubjektí párakozások}

$\mathrm{Az}$ átlagos ( \pm szórás) és a medián (IQR) szubjektíve várható élettartam $81,0( \pm 11,1)$ és 80,0 $(75,0-90,0)$ év, míg a minta statisztikailag várható átlagos életkora 79,6 $( \pm 3,7)$ év és medián életkora 80,5 (76,4-82,0) év volt. (Átlagos különbség: 1,3 év, páros t-próba: $\mathrm{p}<0,001$; medián különbség: 0,5 év, előjelteszt: p = 0,197.) A szubjektíve várható egészséges élettartam átlag- $( \pm$ szórás) és medián (IQR) értékei 64,6 ( $\pm 15,2)$ és 64,8 $(56,8-74,8)$ év, míg a minta statisztikailag várható átlag- és medián értékei $70,0(4,2)$ és 68,6 (66,6-73,2) év voltak. (Átlagos különbség: 5,3 év, páros t-próba: $\mathrm{p}<0,001$; medián különbség: 3,8 év, előjelteszt: $p<0,001$.) A fizetett munka befejezésének szubjektíve várt időpontja átlag (+ szórás) 62,7 (10,5) év, a medián (IQR) 65 (60-68) év volt. A 60 év alattiaknál ez az érték 63,3 ( \pm 10,3) év volt, ami 1,7 évvel alacsonyabb, mint az ebben a korosztályban érvényes, 65

\section{A) Férfiak}

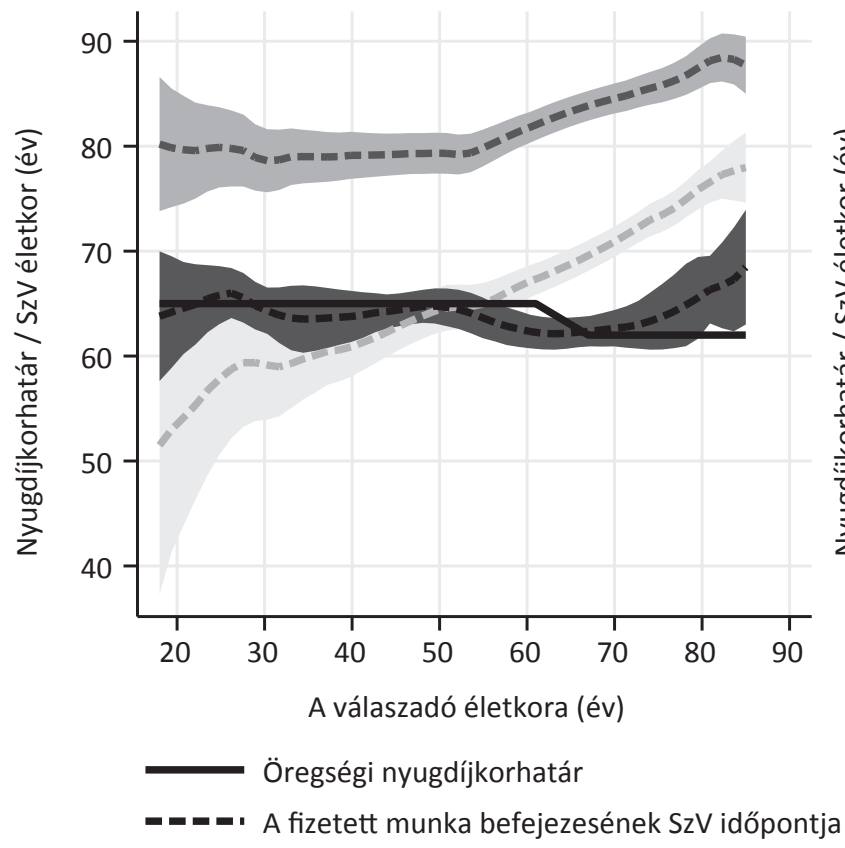

éves öregségi nyugdíjkorhatár ( $\mathrm{p}<0,001)$. A 60-69 évesek átlagosan 61,2 ( $\pm 9,9)$ éves korukig, míg a $\geq 70$ évesek $64,1( \pm 12,4)$ éves korukig végeztek vagy terveztek végezni fizetett munkát. A $\geq 70$ éves korosztályban ez 2,1 évvel magasabb volt, mint a 62 éves öregségi nyugdíjkorhatár, a különbség azonban nem szignifikáns $(\mathrm{p}=0,110)$.

A szubjektíve várható élettartam, az egészséges élettartam és a munkavégzés változását a válaszadók életkorával nemenként az 1. ábra mutatja. A szubjektíve várható élettartamot a 60 év alatti válaszadók körülbelül 80 évre, a 60 év felettiek a korral növekvő mértékben 80 évnél magasabbra becsülték. A szubjektíve várható egészséges élettartam 30 éves kor felett mindkét nem esetén a válaszadók életkorát követve nőtt. A 40 évnél fiatalabb válaszadók esetén az átlagos, szubjektíve várható egészséges élettartam alacsonyabb volt a fizetett munkavégzés szubjektíve várt végénél, míg a fizetett munkavégzés átlagos, szubjektíve várt vége a 60 éves férfi és a 35-65 éves női válaszadók esetén korábbra esett a hivatalos nyugdíjkorhatárnál.

\section{A válaszadók korlátozottsága, informális gondozói szerepe és foglalkoztatottsága, valamint azok összefüggései}

A két nemnél korcsoportonként megvizsgáltuk a korlátozottság, a gondozói szerep és a foglalkoztatottság összefüggéseit. A férfiak 56,9\%-a, míg a nők 45,7\%-a

B) Nők

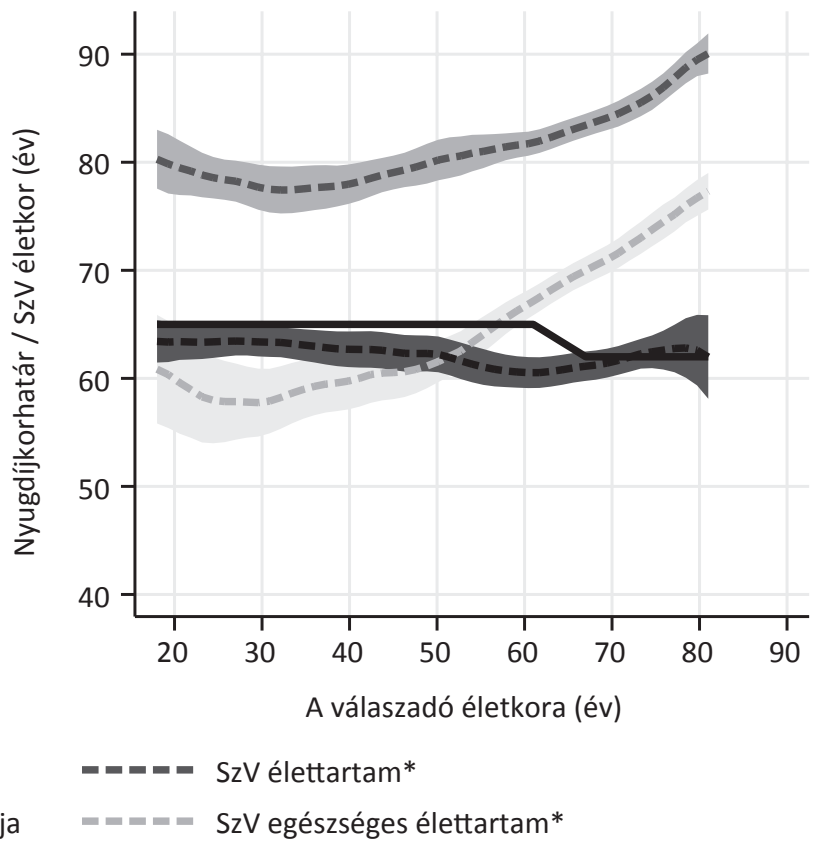

SzV: szubjektíve várt

*Lokális polinom simítás, 95\% megbízhatósági tartomány

1. ábra $\quad$ A szubjektíve várt élettartam, az egészséges élettartam és a fizetett munkavégzés vége életkoronként az öregségi nyugdíjkorhatárral összehasonlítva A) férfiak és B) nők esetén 
végzett fizetett munkát $(\mathrm{p}=0,001)$ a felmérés idején. A fizetett munkavégzők arányát tekintve a különbség a két nem között a 18-29 éves korcsoportban 22,9\% (p = 0,058), a 30-39 éves korcsoportban 26,8\% ( $\mathrm{p}<0,001)$, a 40-49 éveseknél 15,5\% ( $\mathrm{p}=0,006), 50-59$ éves korban $2,9 \%(\mathrm{p}=0,661), 60-69$ éves korban $13,0 \%(\mathrm{p}=0,005)$ és 70 év felett $1,8 \%(\mathrm{p}=0,622)$ volt. Míg (a bármely szintû) korlátozottsággal élők arányában nem volt szignifikáns különbség a két nem között (férfiak: 38,1\%, nők: $35,9 \% ; \mathrm{p}=0,486)$, addig a nők között szignifikánsan magasabb volt az informális gondozók aránya (43,3\%) a férfiakhoz képest $(34,9 \%)(\mathrm{p}=0,010)$. A 2 ábra mutatja a foglalkoztatottság, a gondozói szerep és a korlátozottság megoszlását korcsoportonként a két nem között. A 65 évesnél fiatalabb korosztályban a következő csoportok arányában találtunk szignifikáns különbséget a két nem között: nem dolgozik, nem informális gondozó és nem korlátozott (nők: 15,3\%, férfiak 6,6\%; p<0,001; a különbség a szülőképes korban levő nők esetén volt jelentős); nem dolgozik, informális gondozó és nem korlátozott (nók: 11,5\%, férfiak: $2,8 \%$; $<<0,001$ ); dolgozik, nem informális gondozó és nem korlátozott (nők: $26,8 \%$, férfiak 41,9\%; p<0,001). 65 éves kor felett a nem dolgozó, nem korlátozott informális gondozók aránya a nők között $(29,1 \%)$ szignifikánsan magasabb volt a férfiakhoz képest $(17,4 \%)(\mathrm{p}=0,037)$, míg a 65 év felett férfiak nagyobb arányban végeztek fizetett munkát $(6,1 \%)$, mint a nők $(0,9 \%)(\mathrm{p}=0,036)$.

\section{A) Férfiak}
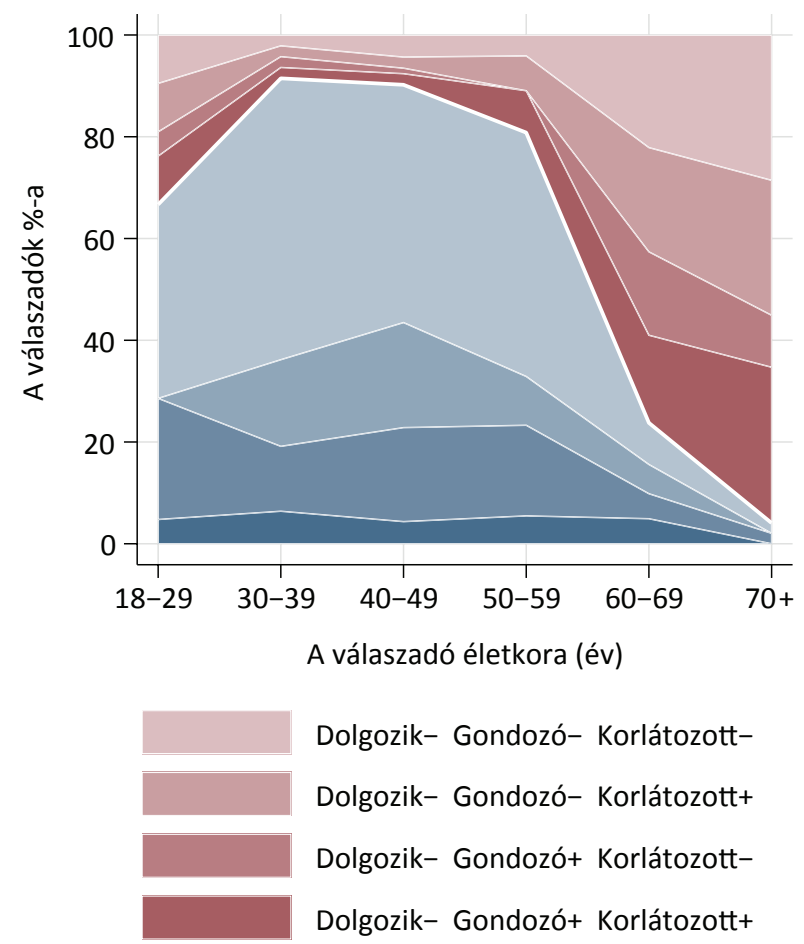

\section{A korlátozottság és a foglalkoztatottság összefüggései a válaszadók valós helyzete és szubjektí várakozásai alapján}

Mintánkban a 65 évnél fiatalabb, dolgozó férfiak 25,1\%-a, a nők 31,9\%-a élt tartós korlátozottsággal $(\mathrm{p}=0,109)$. Mindkét nem esetén megvizsgáltuk a foglalkoztatottság arányának alakulását az életkor előrehaladtával a korlátozott és a nem korlátozott válaszadók körében. Az aktuális válaszokat összehasonlítottuk a szubjektív várakozásokkal (3. ábra). A 65 évnél fiatalabb, nem korlátozott férfiak 86,1\%-ának, míg a korlátozottak 59,0\%-ának volt fizetett munkája $(\mathrm{p}<0,001)$. Ugyanakkor a 30-49 éves férfiak körében a fizetett munkát végzők aránya a nem korlátozottak $(92,9 \%)$ és a korlátozottak $(85,0 \%)$ között nem különbözött szignifikáns mértékben $(\mathrm{p}=0,146)$. Nők esetén a munkaképes korosztályban nem tért el a nem korlátozottak $(59,6 \%)$ és a korlátozottak $(54,8 \%)$ között a fizetett munkát végzők aránya ( $\mathrm{p}=0,357)$.

Férfiak esetén 60/70/80 éves korban a foglalkoztatottsággal kapcsolatos szubjektív várakozások nem különböztek a mintában lokális polinom becsléssel nyert aktuális arányoktól. Nem korlátozott férfiak esetén 60 éves korban a fizetett munkát végzők aránya 53,8\% (95\% CI: 43,3-64,3\%), a 60 éves korra szubjektíve várt foglalkoztatás aránya 59,1\%; a korlátozottak között a fizetett munkát végzők aránya 36,5\% (95\% CI: 24,3-48,8\%), a 60 éves korra szubjektíve várt foglalkoztatás aránya

\section{B) Nők}
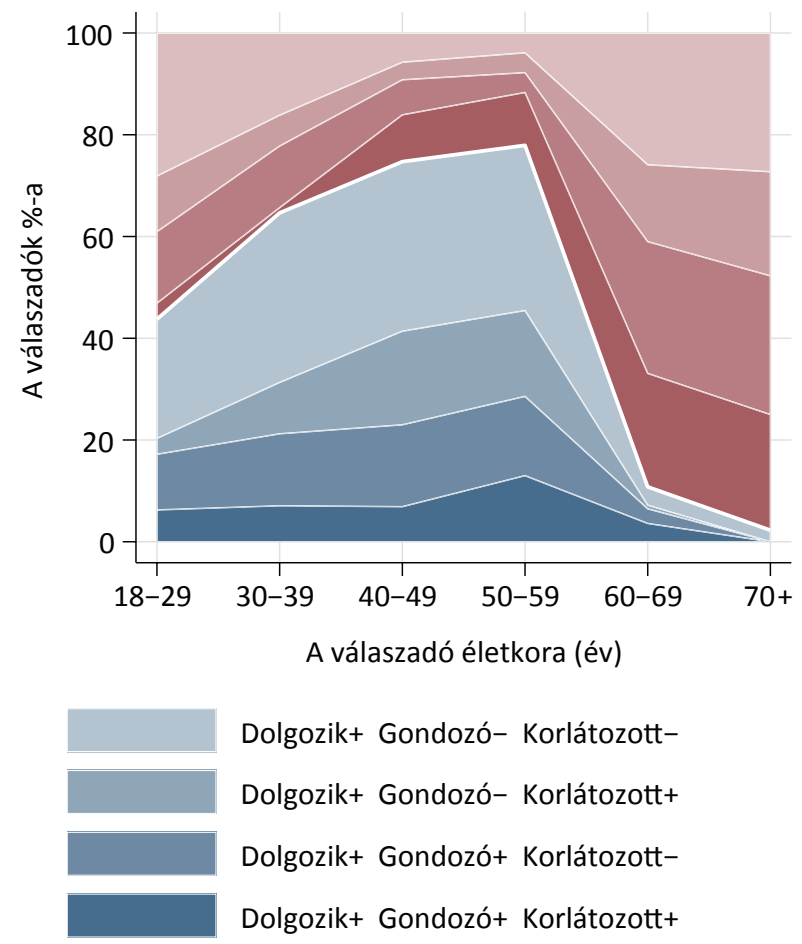

Dolgozik+ Gondozó- Korlátozott-

Dolgozik+ Gondozó- Korlátozott+

Dolgozik+ Gondozó+ Korlátozott-

Dolgozik+ Gondozó+ Korlátozott+

Jelmagyarázat: + igen / - nem

2. ábra | A foglalkoztatottság, a gondozói szerep és a korlátozottság megoszlása korcsoportonként A) férfiaknál és B) nőknél 
A) Férfiak

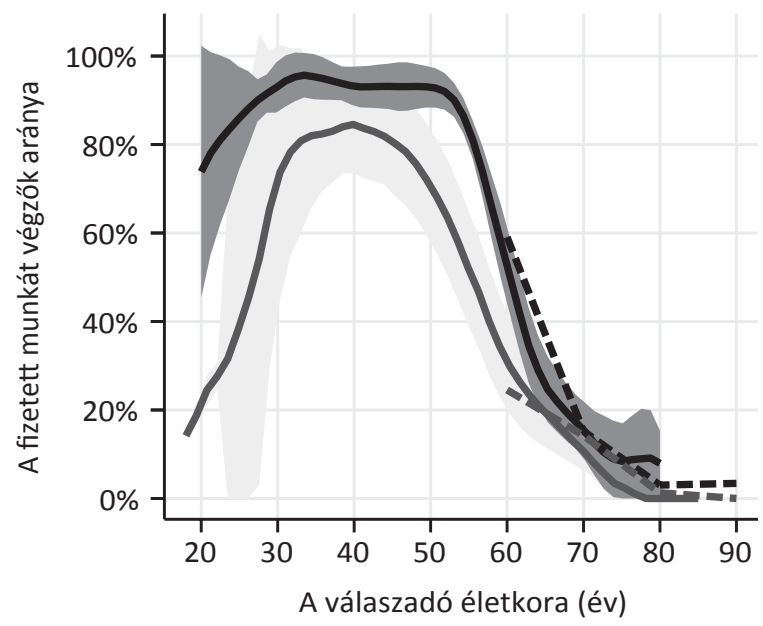

A válaszadó nem korlátozott*

A válaszadó korlátozott*
B) Nők

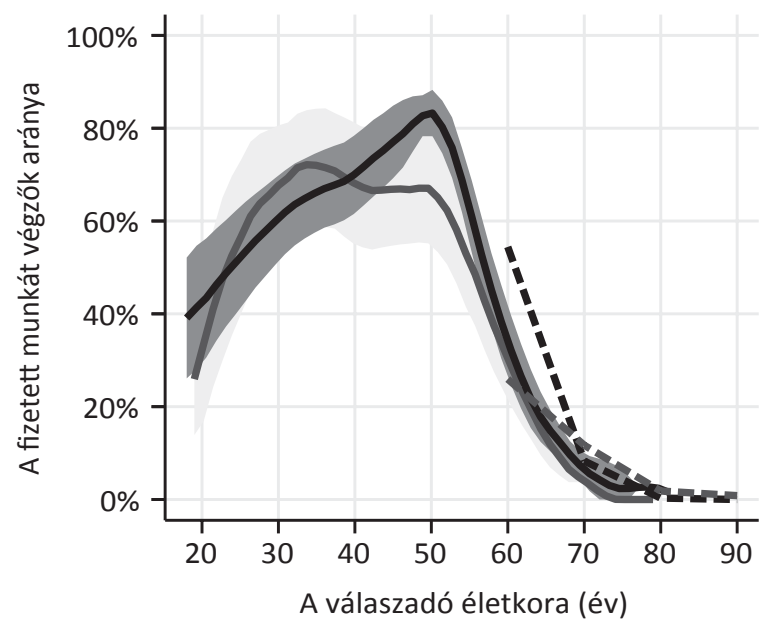

-2-n SzV: nem lesz korlátozott**

-10-1-SzV: korlátozott lesz**

SzV: szubjektív várakozás

*Lokális polinom simítás; 95\% megbízhatósági tartomány

**SzV szerint fizetett munkát végző́k aránya a SzV szerint korlátozott / nem korlátozott egyének között

A) Férfiak

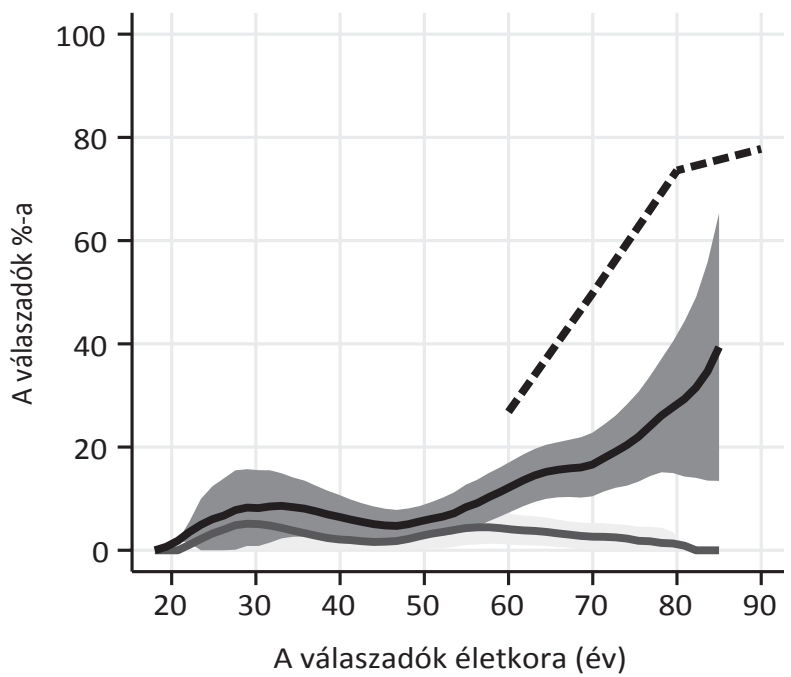

B) Nők

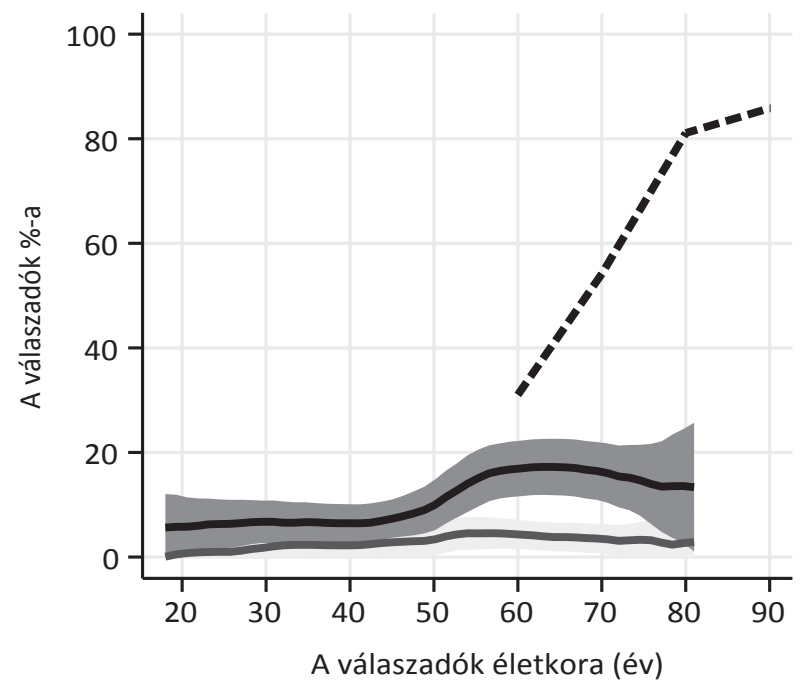

Válaszadó: gondozásra van szüksége

Válaszadó: nincs gondozója, de szüksége lenne rá

SzV: szubjektív várakozás

-20-n SzV: gondozásra lesz szüksége

4. ábra | A gondozást igénylők aktuális és szubjektíve várt aránya a válaszadó A) férfiak és B) nők körében

$24,5 \%$ volt. A nók körében a valós foglalkoztatottság aránya alacsonyabb volt a szubjektíve várt foglalkoztatási aránynál. 60 éves korban a nem korlátozott nők 34,3\%ának (95\% CI: 25,1-43,5\%) volt fizetett munkája, míg a 60 éves korra szubjektíve várt foglalkoztatás aránya
$54,4 \%$ volt. A korlátozott csoportban a valós és a szubjektíve várt foglalkoztatás 60 éves korban hasonló volt, 70 éves korban azonban a szubjektíve várt foglalkoztatás aránya $11,7 \%$ volt a valós $0,5 \%$-kal szemben $(95 \% \mathrm{CI}$ : $0-5,6 \%)$. 


\section{Gondozási igények a válaszadók valós helyzete és szubjektín várakozásai alapján}

A 914 válaszadóból 102 jelzett megkapott vagy kielégítetlen gondozási igényt. A 65 évesnél fiatalabbak esetében a gondozást igénylók aránya a férfiak között numerikusan alacsonyabb volt $(7,6 \%)$, mint a nók között $(10,0 \%)(p=0,280)$, a 65 éves és idősebb korosztályban viszont több férfinak $(20,0 \%)$, mint nőnek $(15,5 \%)$ volt igénye gondozásra $(\mathrm{p}=0,373)$. A különbség nem volt szignifikáns. Mindkét nem esetén a gondozási igényt jelzők között hasonló volt azok aránya, akiknek nem volt gondozójuk (férfiak: 26,7\%, nők: 26,35; p = 0,968). Az átlagos gondozási idő azonban eltérő volt a nemek között. A 65 év alatti korosztályban a férfiak hetente átlagosan ( \pm szórás) $0,9( \pm 0,6)$, a nók $1,3( \pm 0,3)$ óra gondozásban részesültek $(\mathrm{p}=0,590)$, míg a 65 éves és idősebb korosztályban a heti átlagos ( \pm szórás) gondozási idő férfiaknál $3,4( \pm 1,0)$, nőknél $0,9( \pm 0,3)$ óra volt $(\mathrm{p}=0,028)$.

A 4. ábra mutatja a szubjektíve várt gondozási igényeket a valós gondozási igényekhez képest. A mintában $60 / 70 / 80 / 90$ éves korára a férfiak 26,8/49,8/ $73,6 / 77,8 \%$-a, míg a nók $31,0 / 54,1 / 81,1 / 85,8 \%$-a gondolta, hogy szüksége lesz gondozóra. A szubjektíve várt heti átlagos gondozási idő ezekre az életkorokra férfiaknál 2,8/4,7/6,1/11,2 óra, míg nőknél 1,9/3,7/8,3/14,6 óra volt. A különbség a férfiak és a nók között nem volt szignifikáns egyik időpontban sem. A szubjektíve várt gondozási idő azonban elsősorban a nók körében magasabb volt a jelen minta aktuális gondozási idejénél, ami átlagosan (95\% CI) 60/70/80 éves

\section{A) Férfiak}
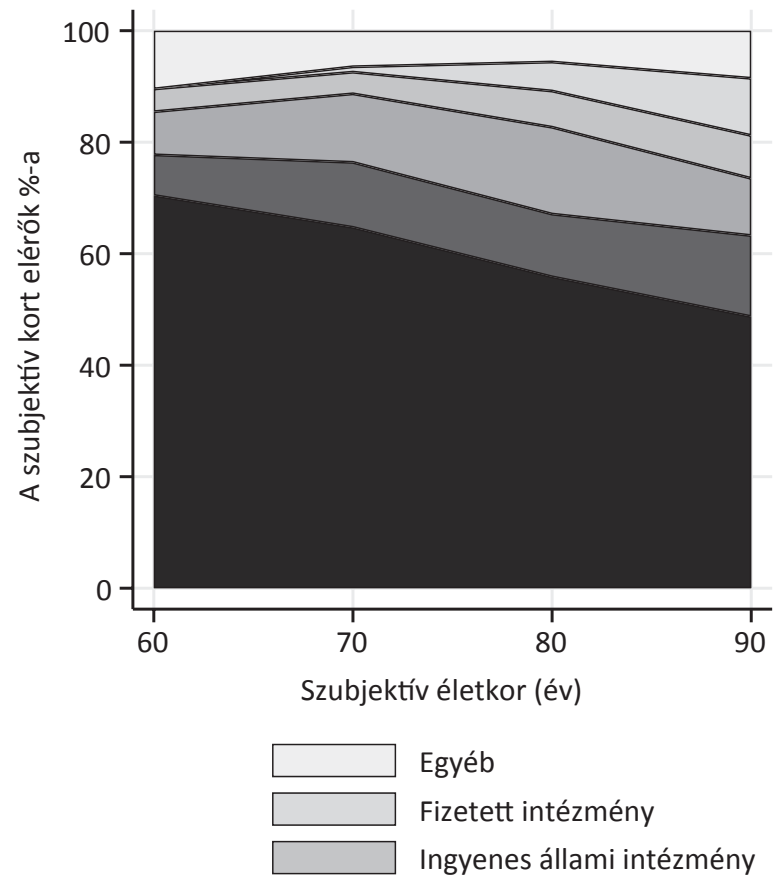

korban a férfiaknál heti $0,9(0,0-2,0) / 2,6(1,0-4,2) / 5,0$ $(0,8-9,2)$ óra, a nóknél heti $1,4(0,8-2,0) / 1,2(0,5-$ $1,9) / 0,7(0,0-1,6)$ óra volt.

A mintánkban az összes gondozási idő 79\%-a informális gondozásból származott, és a gondozásban részesülő válaszadók 89,3\%-át informális gondozó, 9,3\%-át fizetett gondozó, 2,7\%-át informális és fizetett gondozó is, és 1,3\%-át egyéb gondozó segítette. A szubjektíve várt ellátási formák megoszlását a szubjektíve várható élettartam és a nemek bontásában az 5. ábra mutatja be. Azok között, akik úgy gondolják, hogy megélik a 60 éves életkort, $76,9 \%$ számít saját otthonában vagy családtagjaihoz költözve informális gondozásra, 10,8\% saját otthonában vagy intézményben fizetett gondozóra és 9,5\% egyéb gondozóra 60 évesen. A legalább 80 éves élettartamra számító válaszadók között ezek az arányok 80 évesen $61,3 \%, 26,1 \%$, illetve $12,5 \%$.

\section{A korlátozottsággal, a foglalkoztatottsággal és a gondozási igénnyel kapcsolatos szubjektiv várakozások magyarázó tényezối nemek szerint}

Mind a korlátozottság kezdetének, mind a gondozási igény kezdetének szubjektíve várt életkorát a válaszadók jelen egészségérzete és életkora befolyásolta a legnagyobb mértékben (2. táblázat). Az egészséget meghatározó szociodemográfiai tényezők a szubjektíve várt korlátozottság és gondozási igény kezdetével a várt irányú összefüggést mutatták, a nemek közötti kisebb különbségekkel: a magasabb iskolai végzettség, a magasabb jövedelem és a fizetett munkavégzés általában néhány

B) Nők

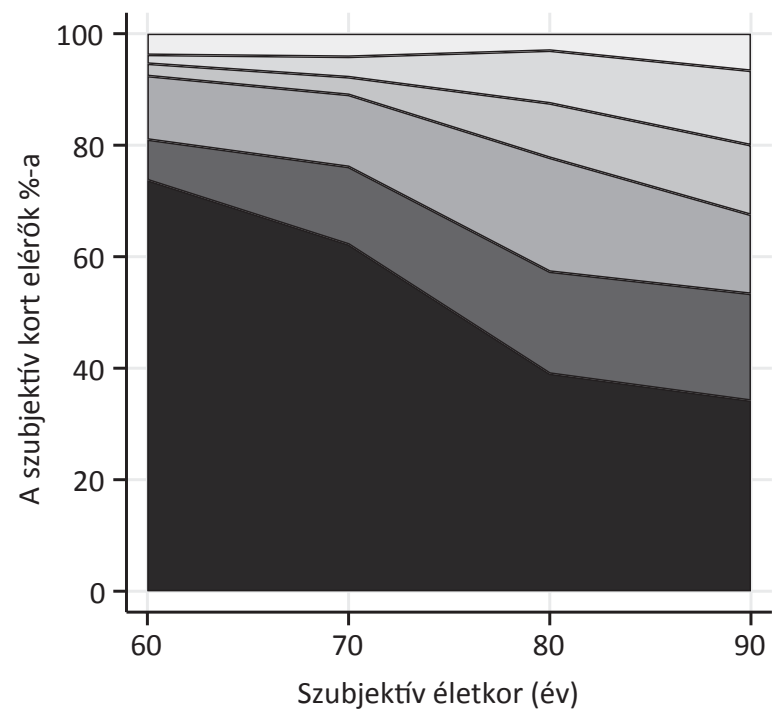

Saját otthonában fizetett segítő

Családtagokhoz költözik

A saját otthonában önkéntes segítő

5. ábra | A szubjektíve várt ellátási formák megoszlása a kor függvényében a válaszadó A) férfiak és B) nők körében 
2. táblázat |Az intervallumregressziós elemzés eredményei

\begin{tabular}{|c|c|c|c|c|c|c|c|c|c|c|c|c|c|}
\hline & & \multicolumn{4}{|c|}{$\begin{array}{l}\text { Szubjektív várakozás: a korlátozottság } \\
\text { kezdete (egészséges élettartam) }\end{array}$} & \multicolumn{4}{|c|}{$\begin{array}{l}\text { Szubjektív várakozás: a fizetett } \\
\text { munkavégzés vége }\end{array}$} & \multicolumn{4}{|c|}{$\begin{array}{l}\text { Szubjektív várakozás: a gondozási } \\
\text { igény kezdete }\end{array}$} \\
\hline & & \multicolumn{2}{|c|}{ Férfiak } & \multicolumn{2}{|c|}{ Nők } & \multicolumn{2}{|c|}{ Férfiak } & \multicolumn{2}{|c|}{ Nók } & \multicolumn{2}{|c|}{ Férfiak } & \multicolumn{2}{|c|}{ Nók } \\
\hline & & Koeff. & $\mathrm{p}$ & Koeff. & $\mathrm{p}$ & Koeff. & $\mathrm{p}$ & Koeff. & $\mathrm{p}$ & Koeff. & $\mathrm{p}$ & Koeff. & $\mathrm{p}$ \\
\hline \multirow[t]{2}{*}{ Kor } & Év & $0,9 \dagger$ & 0,140 & $-0,6 \dagger$ & 0,092 & $-0,3$ & 0,192 & $-0,1$ & 0,573 & $-0,0 \dagger$ & 0,973 & $-0,1 \dagger$ & 0,834 \\
\hline & $\hat{E}^{2}{ }^{2}$ & $-0,0 \dagger$ & 0,309 & $0,0 * * \dagger$ & 0,002 & 0,0 & 0,236 & 0,0 & 0,682 & $0,0 \dagger$ & 0,169 & $0,0^{*} \dagger$ & 0,027 \\
\hline \multirow{4}{*}{$\begin{array}{l}\text { Közeli } \\
\text { hozzátar- } \\
\text { tozók } \\
\text { élettartama }\end{array}$} & 65-74 év & 2,1 & 0,476 & $-1,7$ & 0,578 & 0,4 & 0,835 & 1,5 & 0,345 & $-1,7$ & 0,459 & 0,6 & 0,736 \\
\hline & 75-84 év & 3,4 & 0,216 & 1,5 & 0,564 & 1,3 & 0,447 & 0,2 & 0,882 & 0,0 & 0,990 & 2,3 & 0,163 \\
\hline & 85-94 év & 5,5 & 0,072 & 1,3 & 0,651 & 2,0 & 0,362 & 0,3 & 0,856 & 2,7 & 0,259 & $4,2^{*}$ & 0,028 \\
\hline & $95+$ év & 4,5 & 0,464 & $-0,6$ & 0,944 & 0,7 & 0,806 & 0,7 & 0,778 & $-10,7$ & 0,070 & 6,0 & 0,205 \\
\hline \multirow{2}{*}{$\begin{array}{l}\text { Iskolai } \\
\text { végzettség }\end{array}$} & Általános iskola & $-2,0$ & 0,328 & $-1,1$ & 0,500 & $-0,5$ & 0,674 & $-3,2^{*}$ & 0,011 & 0,8 & 0,557 & $-2,3$ & 0,053 \\
\hline & \begin{tabular}{|l|}
$\begin{array}{l}\text { Egyetem / } \\
\text { föiskola }\end{array}$ \\
\end{tabular} & 1,8 & 0,313 & 0,1 & 0,945 & $3,0^{*}$ & 0,012 & 1,9 & 0,085 & $3,0^{*}$ & 0,024 & $-1,7$ & 0,147 \\
\hline \multirow[t]{2}{*}{ Jövedelem } & \begin{tabular}{|l|} 
Alsó ötöd \\
\end{tabular} & 0,7 & 0,774 & 2,6 & 0,180 & $-1,6$ & 0,338 & 1,6 & 0,289 & 0,1 & 0,938 & 0,2 & 0,907 \\
\hline & Felső ötöd & 2,3 & 0,227 & $3,2^{*}$ & 0,048 & 0,0 & 0,971 & $-1,9$ & 0,088 & 1,1 & 0,393 & 1,4 & 0,210 \\
\hline \multirow[t]{3}{*}{ Lakóhely } & Megyeszékhely & 0,3 & 0,908 & 2,6 & 0,157 & $-1,4$ & 0,352 & $-1,9$ & 0,099 & $-1,1$ & 0,554 & 1,9 & 0,143 \\
\hline & Város & 0,7 & 0,781 & 0,5 & 0,809 & $-3,1^{*}$ & 0,037 & $-2,3^{*}$ & 0,039 & $-1,5$ & 0,356 & 0,4 & 0,756 \\
\hline & Község & 0,8 & 0,742 & $-1,9$ & 0,384 & $-3,0^{*}$ & 0,045 & $-2,5^{*}$ & 0,026 & $-0,7$ & 0,698 & $-0,2$ & 0,869 \\
\hline $\begin{array}{l}\text { Foglalkoz- } \\
\text { tatottság }\end{array}$ & $\begin{array}{l}\text { Fizetett munkát } \\
\text { végez }\end{array}$ & $-2,8$ & 0,308 & 2,5 & 0,174 & - & - & - & - & 0,3 & 0,855 & $3,1^{*}$ & 0,012 \\
\hline $\begin{array}{l}\text { Családi } \\
\text { állapot }\end{array}$ & \begin{tabular}{|l|} 
Házastárs / \\
élettársi \\
kapcsolat
\end{tabular} & $-0,5$ & 0,830 & $-1,0$ & 0,544 & 1,1 & 0,482 & 1,0 & 0,425 & $-3,2^{*}$ & 0,046 & 1,4 & 0,235 \\
\hline \multirow[t]{2}{*}{ GALI } & \begin{tabular}{|l|l|}
$\begin{array}{l}\text { Súlyosan } \\
\text { korlátozott }\end{array}$ \\
\end{tabular} & - & - & - & - & $-0,3$ & 0,930 & $-0,4$ & 0,915 & $-8,2^{*}$ & 0,026 & $-0,8$ & 0,818 \\
\hline & $\begin{array}{l}\text { Korlátozott, de } \\
\text { nem súlyosan }\end{array}$ & - & - & - & - & $-0,8$ & 0,613 & 1,7 & 0,125 & $-3,0^{*}$ & 0,013 & $-1,0$ & 0,384 \\
\hline \multirow[t]{2}{*}{ Gondozás } & Van segító & $-17,7$ ** & 0,005 & $-6,8$ & 0,111 & $-2,6$ & 0,295 & $-2,7$ & 0,316 & - & - & - & - \\
\hline & $\begin{array}{l}\text { Nincs segítő, de } \\
\text { szükség lenne rá }\end{array}$ & $-24,9$ ** & 0,010 & $-0,5$ & 0,931 & $-6,9^{*}$ & 0,045 & 1,0 & 0,700 & - & - & - & - \\
\hline \multirow{2}{*}{$\begin{array}{l}\text { Felnőttek } \\
\text { száma a } \\
\text { háztartás- } \\
\text { ban }\end{array}$} & 2 felnőtt & $-2,8$ & 0,244 & 0,6 & 0,766 & $-2,2$ & 0,181 & $-2,1$ & 0,154 & 1,9 & 0,203 & $-0,8$ & 0,517 \\
\hline & $>2$ felnótt & 0,7 & 0,795 & 2,0 & 0,415 & 1,1 & 0,523 & $-3,1^{*}$ & 0,047 & 2,9 & 0,124 & $-1,5$ & 0,334 \\
\hline \multirow{2}{*}{$\begin{array}{l}\text { Gyermekek } \\
\text { száma a } \\
\text { háztar- } \\
\text { tásban }\end{array}$} & 1 gyermek & $-6,5^{*}$ & 0,024 & 1,3 & 0,552 & $-0,1$ & 0,950 & 0,7 & 0,563 & 2,3 & 0,195 & 2,6 & 0,104 \\
\hline & $>1$ gyermek & 5,5 & 0,121 & 1,4 & 0,590 & 4,4 & 0,054 & $-1,7$ & 0,357 & 3,8 & 0,113 & 4,8 ** & 0,009 \\
\hline \multirow{4}{*}{$\begin{array}{l}\text { Jelen } \\
\text { egészség- } \\
\text { érzet }\end{array}$} & Jó & $-11,8 * *$ & 0,000 & $-8,7$ ** & 0,000 & 0,6 & 0,689 & $-1,5$ & 0,161 & $-5,5^{*}$ & 0,010 & $-6,3^{* *}$ & 0,001 \\
\hline & Elfogadható & $-21,6^{* *}$ & 0,000 & $-18,4^{* *}$ & 0,000 & $-0,4$ & 0,860 & $-5,0^{\text {** }}$ & 0,001 & $-7,0^{* *}$ & 0,007 & $-11,1^{* *}$ & 0,000 \\
\hline & Rossz & $-34,8^{* *}$ & 0,000 & $-23,6^{* *}$ & 0,000 & $-3,0$ & 0,304 & $-8,6^{*}$ & 0,013 & $-12,7^{* *}$ & 0,000 & $-17,9^{* *}$ & 0,000 \\
\hline & Nagyon rossz & $-70,0$ ** & 0,000 & $-77,8^{* *}$ & 0,000 & $-12,8$ & 0,255 & $-18,4$ & 0,076 & $-63,4^{* *}$ & 0,000 & $-11,1$ & 0,096 \\
\hline \multirow[t]{2}{*}{ Életmód } & $\begin{array}{l}\text { Olyan egészsé- } \\
\text { gesen él, mint } \\
\text { mások } \\
\end{array}$ & 0,5 & 0,825 & 1,4 & 0,476 & $-1,5$ & 0,264 & $-0,3$ & 0,763 & $-1,1$ & 0,486 & $-0,4$ & 0,698 \\
\hline & \begin{tabular}{|l|} 
Kevésbé él \\
egészségesen, \\
mint mások
\end{tabular} & $-5,3$ & 0,113 & $-4,1$ & 0,117 & $-2,5$ & 0,208 & $-1,2$ & 0,466 & $-4,3$ & 0,051 & $-2,0$ & 0,225 \\
\hline Dohányzás & $\begin{array}{l}\text { Egy éven belül } \\
\text { leszokott }\end{array}$ & 9,1 & 0,060 & $-1,9$ & 0,728 & $-0,4$ & 0,844 & 0,4 & 0,870 & $5,5^{*}$ & 0,038 & $-5,0$ & 0,326 \\
\hline & Dohányzik & $-2,2$ & 0,255 & $-0,9$ & 0,553 & $-0,2$ & 0,882 & $-0,4$ & 0,679 & 1,2 & 0,356 & 0,4 & 0,653 \\
\hline $\begin{array}{l}\text { Alkohol- } \\
\text { fogyasztás }\end{array}$ & $\begin{array}{l}\text { Max. heti 3-4 } \\
\text { nap }\end{array}$ & $6,1^{*}$ & 0,023 & 0,5 & 0,786 & 0,4 & 0,800 & 1,3 & 0,191 & $-1,5$ & 0,432 & 1,5 & 0,216 \\
\hline & Heti $\geq 5$ nap & $9,7 * *$ & 0,002 & 4,1 & 0,457 & 1,1 & 0,646 & 2,1 & 0,366 & $-0,2$ & 0,921 & 0,8 & 0,793 \\
\hline Testmoz- & Heti $1-4$ nap & $-3,0$ & 0,158 & 1,4 & 0,517 & $-1,4$ & 0,265 & $-0,4$ & 0,757 & 0,6 & 0,677 & $-1,2$ & 0,329 \\
\hline gás & Soha & 0,0 & 0,986 & 2,2 & 0,282 & $-1,4$ & 0,277 & $-0,9$ & 0,551 & $-0,4$ & 0,773 & $-1,7$ & 0,187 \\
\hline Testtö- & $<18,5$ & 5,8 & 0,062 & 6,3 & 0,062 & 0,3 & 0,931 & $-1,1$ & 0,609 & $-8,5^{* *}$ & 0,010 & 2,8 & 0,328 \\
\hline megindex & $>30$ & $4,1^{*}$ & 0,011 & 2,2 & 0,137 & $3,8^{* *}$ & 0,002 & 0,3 & 0,811 & 1,1 & 0,347 & $-1,0$ & 0,375 \\
\hline Boldogság & Pont $(0-10)$ & 0,3 & 0,471 & $1,3^{* *}$ & 0,000 & 0,1 & 0,845 & $-0,4$ & 0,077 & 0,2 & 0,560 & 0,3 & 0,258 \\
\hline Konstans & & $42,1^{*}$ & 0,012 & $62,0^{* *}$ & 0,000 & $75,0^{* *}$ & 0,000 & $73,4^{* *}$ & 0,000 & $64,0^{* *}$ & 0,000 & $57,7^{* *}$ & 0,000 \\
\hline $\mathrm{N}$ & & 331 & & 425 & & 314 & & 400 & & 331 & & 425 & \\
\hline
\end{tabular}

${ }^{*} \mathrm{p}<0,05 ;{ }^{*} \mathrm{p}<0,01 ;$ †Együttes Wald-teszt $\mathrm{p}<0,01$

GALI = Globális Tevékenységkorlátozottsági Mutató 
évvel későbbi korlátozottsággal vagy gondozási igénnyel mutatott összefüggést. A szubjektív életmód sem a férfiaknál, sem a nóknél, az objektív életmódbeli kockázati tényezők pedig a nőknél sem a szubjektíve várt korlátozottságot, sem a szubjektíve várt gondozási igényt nem befolyásolták. Férfiaknál azonban az alkoholfogyasztás és az elhízás a várttal ellentétes irányú kapcsolatban állt a szubjektíve várható egészséges élettartammal: a mérsékelt és túlzottan gyakori alkoholfogyasztás az absztinenciához képest, valamint az elhízás az ideális testsúlyhoz képest későbbre tolódott szubjektíve várt korlátozottsággal volt összefüggésben. Ezenkívül férfiak esetén a dohányzásról frissen leszokott egyének szubjektíve várt gondozási igénye a nem dohányzókhoz képest később, míg a kórosan alacsony testtömegindexszel rendelkezőké az ideális testsúlyúakhoz képest korábban kezdődött.

A fizetett munkavégzés szubjektíve várt vége nem mutatott kapcsolatot az életkorral, azonban a magasabb végzettséggel rendelkezők és a fóváros/megyeszékhelyek lakói néhány évvel hosszabb foglalkoztatottságra számítottak a vidéki városok vagy községek lakóihoz képest.

A férfiak és a nők szubjektív várakozásait befolyásoló tényezők között az életmódbeli rizikókon túl további különbségek is megfigyelhetők voltak. A gondozás iránti igény a férfiaknál mind a korlátozottság, mind a foglalkoztatás szubjektíve várt életkorával negatív összefüggést mutatott, míg a nóknél nem. Az egészségprobléma miatti tartós korlátozottság esetén a férfiak a szubjektíve várt gondozási igény korábbi kezdetét jelezték, míg a nók nem. Ugyanakkor a férfiaknál a jelen egészségi állapot nem befolyásolta a foglalkoztatás végének szubjektíve várt életkorát, míg a nőknél igen. Továbbá a pszichoszociális tényezők - boldogság, a háztartás összetétele, családi állapot és a közeli családtagok életkilátásai - is eltérően befolyásolták a férfiak és a nők szubjektív várakozásait.

\section{Megbeszélés}

Kutatásunkban elsőként alkalmaztuk a GALI-kérdőívet annak felmérésére, hogy milyen egészségi állapotokat vár a lakosság az idősebb életkorokra, valamint a szubjektíve várható egészséges élettartam becslésére, melyeket a foglalkoztatással és a gondozási igénnyel kapcsolatos elgondolásokkal együtt vizsgáltunk. Kutatásunk főbb megállapításai a következők. A válaszadók a szubjektíve várható egészséges élettartamot a statisztikailag várható egészséges élettartamhoz képest átlagosan 5,3 évvel becsülték rövidebbre. A fiatalabb korosztály rövidebbre becsülte egészséges élettartamát, mint a fizetett munkavégzés befejezésének idejét, azaz úgy gondolják, korlátozottsággal élve fognak még fizetett munkát végezni. A korlátozottság, a foglalkoztatás és a gondozási igények tekintetében mind a mintában mért valós adatok, mind a szubjektív várakozások tekintetében jelentős különbségeket találtunk a két nem között.

A mintában 60 éves korban a nem korlátozott nők foglalkoztatási aránya hasonló volt, mint a korlátozottaké, míg a szubjektív várakozás szerint nem korlátozottak esetén várt foglalkoztatási arány jelentôsen meghaladta a szubjektív várakozás szerint korlátozottak esetén várt foglalkoztatási arányt. A munkaképes korú férfiak között a nőknél magasabb arányban voltak azok, akik dolgoznak, nem korlátozottak és nem informális gondozók, míg a nők között (65 év alatt és felett egyaránt) azok aránya volt magasabb, akik nem dolgoznak, nem korlátozottak, de informális gondozók. A férfiak és a nők által várt gondozási igények hasonlók voltak, ezzel szemben a mintában a 65 év feletti férfiak időben több gondozásban részesültek. A férfiaknál a szubjektíve várható egészséges élettartam és a szubjektíve várt gondozási igény között szignifikáns összefüggés volt kimutatható, míg a nőknél nem. Összességében tehát amíg a nők nagyobb valószínûséggel válnak informális gondozóvá, mint a férfiak, korlátozottság esetén kevésbé számítanak arra, hogy megkapják a szükséges segítséget a családtagoktól, mint a férfiak. A mintában tapasztalt valós arányhoz képest a jövőben az életkor előrehaladtával azonban mindkét nem képviselői egyre nagyobb mértékben túlbecsülték a fizetett és az egyéb, nem informális gondozók elérhetőségét.

Az életmódbeli tényezők a nők esetében nem mutattak összefüggést a szubjektív várakozásokkal, míg a túlzott gyakorisággal alkoholt fogyasztó vagy elhízott férfiak hosszabb (!) egészséges élettartamra számítottak. A férfiak szubjektív várakozásai tehát mind az életmódbeli tényezők és az egészség, mind az egészség és a munkavégzés összefüggései tekintetében hibásnak bizonyultak.

Korábbi nemzetközi kutatások kimutatták, hogy a szubjektíve várható élettartamot a közeli hozzátartozók élettartama $[37,38]$, a válaszadó egészségi állapota [20, 38], életkora [38, 39], neme [38, 40], életmódbeli kockázati tényezői $[38,41]$, szocioökönómiai státusza [42] és számos pszichológiai, valamint pszichoszociális tényező, köztük a boldogság vagy a társas kapcsolatok [38] befolyásolják. Krónikus betegeknél a gondozási igény is befolyásolta a szubjektív életkilátásokat [23]. A szubjektíve várt életminőséget hasonló tényezők befolyásolták korábbi holland és hazai kutatásokban $[20,22,43]$. Továbbá a szubjektíve várható élettartam összefüggést mutatott az emberek valós mortalitási kockázatával [39], a nyugdíjba vonulással, megtakarításokkal és fogyasztással kapcsolatos döntéseivel [15, 17] és életmódjával [19]. Eredményeink a szubjektíve várt élethosszt magyarázó, fent felsorolt faktorok összefüggését a korlátozottsággal, a foglalkoztatottsággal és a gondozási igényekkel kapcsolatos szubjektív várakozásokkal is megerősítették, és az egyes faktorok szerepét és a nemek közti különbségeket illetôen tovább árnyalták. Ugyanakkor eredményeink közvetlenül nem hasonlíthatók össze a szubjektíve várt életminőséget mérő vizsgálatokkal, mivel az általunk alkalmazott GALI- és a korábbi kutatásokban alkalmazott EQ-5D-kérdőív az egészség más-más aspektusait mérik. Továbbá a túlélő hatásnak (hiszik-e, hogy megélik a kérdezett életkort) köszönhetően a szubjektív várakozásokkal kapcsolatos kutatások nagyon érzékenyek a minta kor- 
összetételére, amit a különböző kutatások eredményeinek összehasonlításakor szintén figyelembe kell venni [20].

Kutatásunk erőssége, hogy a szubjektíve várható egészséges élettartam mérésére a GALI-kérdőívet alkalmaztuk, melynek révén eredményeink összehasonlíthatók a várható egészséges élettartamra vonatkozó hivatalos becslésekkel. Továbbá felmérésünket kellően nagy elemszámú, reprezentatív mintán végeztük. Ugyanakkor kutatásunk limitációja, hogy az életkor és az iskolai végzettség tekintetében tapasztalt eltérések a férfi és a női válaszadói csoportok között befolyásolhatták az eredményeket. Ezenfelül a vizsgálat idejében korlátozottságot jelző válaszadóknál a korlátozottság valós kezdete nem volt ismert, ezt a szubjektíve várható egészséges élettartam becslésekor minden válaszadónál azonos feltételezések alapján pótoltuk. A szubjektíve várható élettartamot magyarázó tényezők vizsgálatát azonban az intervallumregresszió alkalmazásának köszönhetően ezek a feltételezések nem befolyásolták.

Az egészségügyi rendszerek betegközpontú átalakulásával párhuzamosan értékelődik fel a betegek szerepe saját egészségük megőrzésében, javításában [44, 45]. Ezzel együtt nő a betegek beszámolóin alapuló kimenetek jelentősége (patient-reported outcome measures, PROM) [46, 47] az egészségügyi beavatkozások és az egészségügyi rendszerek hatékonyságának értékelése során. Ám nem pusztán az a fontos kérdés, hogy az emberek milyennek ítélik meg saját egészségi állapotukat, hanem az is, hogy az miként befolyásolja az egészséggel vagy a jóllétükkel kapcsolatos magatartásukat, döntéseiket. Kutatásunk rámutatott, hogy az egészséggel, munkával és gondozással kapcsolatos szubjektív várakozások eltérőek a populációban mért valós adatoktól, és jelento"sen különböznek a nemek között. Kutatásunkban a szubjektív várakozások egyik legfontosabb meghatározó tényezője a válaszadók jelenlegi egészségérzete volt. Az további kutatást igényel, hogy az egészségi ok miatti korlátozottsággal, gondozási igényekkel és munkavégzéssel kapcsolatos szubjektív várakozások miként befolyásolják az emberek egészségmagatartását, és ez hogyan járulhat hozzá az egészséges(ebb) életmód, az orvos és beteg közötti közös döntéshozatal vagy kedvező terápiás együttmúködés kialakításához.

Anyagi támogatás: A tanulmány alapjául szolgáló kutatást az Emberi Erőforrások Minisztériuma által meghirdetett Felsőoktatási Intézményi Kiválósági Program támogatta, a Budapesti Corvinus Egyetem 'Pénzügyi és Lakossági Szolgáltatások' tématerületi programjának (20764-3/2018/FEKUTSTRAT) keretében.

Szerzői munkamegosztás: A kutatás megtervezése, adatfelvétel: P. M., G. L., K. L. Az adatok elemzése: Z. Zs., K. Á. A kézirat vázlata: P. M., Z. Zs. Az eredmények értelmezése: minden szerző. A cikk végleges változatát valamennyi szerző elolvasta és jóváhagyta.
Érdekeltségek: A tanulmány megírásával kapcsolatosan Z. Zs., G. L. és P. M. munkáját az Innovációs és Technológiai Minisztérium által meghirdetett Tématerületi Kiválósági Program 2020 - Intézményi Kiválóság Alprogram támogatta, a Budapesti Corvinus Egyetem 'Pénzügyi és Lakossági Szolgáltatások' tématerületi (TKP2020IKA-02) programjának keretében. P. M. az Euroqol Csoport tagja, amely nonprofit szervezet olyan eszközöket fejleszt és terjeszt, melyek az egészség felmérésére és értékelésére alkalmasak. A többi szerzőnek nincsenek érdekeltségei.

\section{Köszönetnyilvánítás}

A szerzők köszönetet mondanak Beretzky Zsuzsannának és Brodszky Valentinnek (Budapesti Corvinus Egyetem), az Intézményi Kiválóság Alprogram résztvevőinek a kutatáshoz nyújtott segítségért.

\section{Irodalom}

[1] Eurostat. Population structure and ageing. 2020 August. Available from: https://ec.europa.eu/eurostat/statistics-explained/ index.php/Population_structure_and_ageing [accessed: November 16. 2020].

[2] Eurostat. Healthy life years by sex (from 2004 onwards). 2020. Available from: https://ec.europa.eu/eurostat/databrowser/ view/hlth_hlye/default/table?lang=en [accessed: November 16. 2020].

[3] Ministry of Human Resources, Central Customer Service Office. Information about the pension system. [Tájékoztató a nyugdíjrendszerról.] Emberi Erőforrások Minisztériuma, Budapest, 2019. Available from: https://www.kormanyhivatal.hu/download/5/94/25000/nyugdijfüzet_2019.pdf [accessed: November 16. 2020]. [Hungarian]

[4] Eurostat. Total fertility rate, 2020. Available from: http://appsso.eurostat.ec.europa.eu/nui/submitViewTableAction.do [accessed: 16. 11.2020].

[5] Hungarian Central Statistical Office. Population, demography (1900-). [Népesség, népmozgalom (1900-).] Központi Statisztikai Hivatal, Budapest, 2020. Available from: https://www.ksh. hu/docs/hun/xstadat/xstadat_hosszu/h_wdsd001a.html [accessed: November 16. 2020]. [Hungarian]

[6] Hungarian Central Statistical Office. Population of Hungary by gender and age, January 1st, 2020. [Magyarország népességének száma nemek és életkor szerint, 2020. január 1.] Központi Statisztikai Hivatal, Budapest, 2020. Available from: https:// www.ksh.hu/interaktiv/korfak/orszag.html [accessed: November 16. 2020]. [Hungarian]

[7] World Bank. Age dependency ratio (\% of working-age population) - Hungary, 2019. Available from: https://data.worldbank. org/indicator/SP.POP.DPND?locations=HU [accessed: November 16. 2020].

[8] Gyarmati A. Ageing and care for the elderly in Hungary. General survey and problems. Friedrich Ebert Stiftung, Budapest, 2019. Available from: http://library.fes.de/pdf-files/bueros/budapest/15482.pdf [accessed: November 16. 2020].

[9] Baji P, Golicki D, Prevolnik-Rupel V, et al. The burden of informal caregiving in Hungary, Poland and Slovenia: results from national representative surveys. Eur J Health Econ. 2019; 20(Suppl 1): 5-16.

[10] Sándor Z, Látos M, Csabai M. Using PRISM-D drawing test for the examination of associations of perceived social support among inpatients with chronic medical conditions. [ $\mathrm{Az}$ észlelt társas támogatás összefüggéseinek vizsgálati lehetőségei a PRISM-D rajzteszt segítségével kórházi kezelés alatt álló súlyos 
betegek körében.] Orv Hetil. 2020; 161: 1688-1696. [Hungarian]

[11] Kővári E, Kaposi A, Kiss Z, et al. The effect of multimorbidity on functional and quality of life outcomes in women with generalized osteoarthritis. [A multimorbiditás hatása a funkcionális és életminőség-eredményekre generalizált osteoarthrosisban.] Orv Hetil. 2020; 161: 1373-1381. [Hungarian]

[12] Zrubka Zs. Measurement and health economic evaluation of informal care. [Az informális ellátás mérése és egészség-gazdaságtani értékelése.] Orv Hetil. 2017; 158: 1363-1372. [Hungarian]

[13] Kovács G. Changes in disability, reduced working ability and rehabilitation benefits in Hungary between 1990 and 2015 . [A rokkantság, megváltozott munkaképesség, rehabilitációs ellátások változása Magyarországon 1990 és 2015 között.] Orv Hetil. 2019; 160(Suppl 1): 29-36. [Hungarian]

[14] Boncz I, Endrei D, Csákvári T, et al. Health policy indicators of neuromusculosceletal rehabilitation in Hungary. [A neuromusculoskeletalis rehabilitáció szakmapolitikai indikátorai Magyarországon.] Orv Hetil. 2019; 160(Suppl 1): 13-21. [Hungarian]

[15] van Solinge H, Henkens K. Living longer, working longer? The impact of subjective life expectancy on retirement intentions and behavior. [Langer leven, langer werken? De rol van gepercipieerde levensverwachting in het uittredeproces.] Tijdschr Gerontol Geriatr. 2010; 41: 204-213. [Dutch]

[16] Vanajan A, Bültmann U, Henkens K. Why do older workers with chronic health conditions prefer to retire early? Age Ageing 2020; 49: 403-410.

[17] Salm M. Subjective mortality expectations and consumption and saving behaviours among the elderly. Canadian J Econ. 2010; 43: 1040-1057.

[18] Ziegelmann JP, Lippke S, Schwarzer R. Subjective residual life expectancy in health self-regulation. J Gerontol B Psychol Sci Soc Sci. 2006; 61: P195-P201.

[19] Balia S. Survival expectations, subjective health and smoking: evidence from SHARE. Empir Econ. 2014; 47: 753-780.

[20] Péntek M, Brodszky V, Gulácsi ÁL, et al. Subjective expectations regarding length and health-related quality of life in Hungary: results from an empirical investigation. Health Expect. 2014; 17: 696-709.

[21] Péntek M, Gulácsi L, Rojkovich B, et al. Subjective health expectations at biological therapy initiation: a survey of rheumatoid arthritis patients and rheumatologists. Eur J Health Econ. 2014 15(Suppl 1): S83-S92.

[22] Rappange DR, Brouwer WB, van Exel J. A long life in good health: subjective expectations regarding length and future health-related quality of life. Eur J Health Econ. 2016; 17: $577-$ 589.

[23] Péntek M, Brodszky V, Bíró Z, et al. Subjective health expectations of patients with age-related macular degeneration treated with antiVEGF drugs. BMC Geriatr. 2017; 17: 233.

[24] Péntek M, Hajdu O, Rencz F, et al. Subjective expectations regarding ageing: a cross-sectional online population survey in Hungary. Eur J Health Econ. 2019; 20(Suppl 1): 17-30.

[25] EuroQol Research Foundation. EQ-5D-3L User Guide. EuroQol Research Foundation, Rotterdam, 2018. Available from: https://euroqol.org/publications/user-guides [accessed: February 24,2019$]$.

[26] Boros J, Györke J, Pásztorné Stokker E, et al. Results of the 2014 European health information survey. [A 2014-ben végrehajtott Európai lakossági egészségfelmérés eredményei.] Központi Statisztikai Hivatal, Budapest, 2018. Available from: https:// www.ksh.hu/docs/hun/xftp/idoszaki/elef/elef2014_osszefoglalo.pdf [accessed: February 24, 2019]. [Hungarian]

[27] Arora VS, Karanikolos M, Clair A, et al. Data Resource Profile: The European Union Statistics on Income and Living Conditions (EU-SILC). Int J Epidemiol. 2015; 44: 451-461.

[28] Eurostat. Glossary: Healthy life years (HLY), 2015. Available from: https://ec.europa.eu/eurostat/statistics-explained/in-
dex.php/Glossary:Healthy_life_years_(HLY) [accessed: February 24,2019 ].

[29] Cox B, van Oyen H, Cambois E, et al. The reliability of the Minimum European Health Module. Int J Public Health 2009; 54: 55-60.

[30] Eurostat. Glossary: Minimum European Health Module (MEHM), 2019. Available from: https://ec.europa.eu/eurostat/statistics-explained/index.php/Glossary:Minimum_European_Health_Module_(MEHM) [accessed: February 24, 2019].

[31] Veenhoven R. Happiness in nations: overview of happiness surveys using measure type: 112G / 11-step numeral happiness. In: World Database of Happiness. Erasmus University Rotterdam, Happiness Economics Research Organisation, Rotterdam, 1993. Available from: http://worlddatabaseofhappiness.eur.nl [accessed: February 24, 2019].

[32] Faragó M. Healthy life expectancy in Hungary, 2011. [Egészségesen várható élettartamok Magyarországon, 2011.] Stat Szle. 2015; 93: 633-661. [Hungarian]

[33] World Health Organization. WHO methods for life expectancy and healthy life expectancy. In: Global Health Estimates Technical Paper WHO/HIS/HSI/GHE/2014.5. Department of Health Statistics and Information Systems, WHO, Geneva, 2014. Available from: https://www.who.int/healthinfo/statistics/LT_method_1990_2012.pdf [accessed: February 24, 2019].

[34] Hungarian Central Statistical Office. Demographic yearbook 2019. [Demográfiai évkönyv - 2019.] Központi Statisztikai Hivatal, Budapest, 2019; pp. 227. [Hungarian]

[35] Stata Corp. Stata Statistical Software: Release 16. StataCorp LLC, College Station, TX, 2019.

[36] Eysenbach G, Wyatt J. Using the Internet for surveys and health research. J Med Internet Res. 2002; 4: El3.

[37] Hamermesh DS. Expectations, life expectancy, and economic behavior. Quarterly J Econ. 1985; 100: 389-408.

[38] Griffin B, Loh V, Hesketh B. A mental model of factors associated with subjective life expectancy. Soc Sci Med. 2013; 82: 7986.

[39] van Solinge H, Henkens K. Subjective life expectancy and actual mortality: results of a 10-year panel study among older workers. Eur J Ageing 2018; 15: 155-164.

[40] Mirowsky J. Subjective life expectancy in the US: correspondence to actuarial estimates by age, sex and race. Soc Sci Med. 1999; 49: 967-979.

[41] Dieteren CM, Brouwer WB, van Exel J. How do combinations of unhealthy behaviors relate to attitudinal factors and subjective health among the adult population in the Netherlands? BMC Public Health 2020; 20: 441.

[42] Popham F, Mitchell R. Self-rated life expectancy and lifetime socio-economic position: cross-sectional analysis of the British household panel survey. Int J Epidemiol. 2007; 36: 58-65.

[43] Brouwer WB, van Exel NJ. Expectations regarding length and health related quality of life: some empirical findings. Soc Sci Med. 2005; 61: 1083-1094.

[44] Hart JT. Clinical and economic consequences of patients as producers. J Public Health Med. 1995; 17: 383-386.

[45] Batalden M, Batalden P, Margolis P, et al. Coproduction of healthcare service. BMJ Qual Saf. 2016; 25: 509-517.

[46] Weszl M, Rencz F, Brodszky V. Is the trend of increasing use of patient-reported outcome measures in medical device studies the sign of shift towards value-based purchasing in Europe? Eur J Health Econ. 2019; 20(Suppl 1): 133-140.

[47] Øvretveit J, Zubkoff L, Nelson EC, et al. Using patient-reported outcome measurement to improve patient care. Int J Qual Health Care 2017; 29: 874-879.

(Zrubka Zsombor dr., Budapest, Bécsi út 96/b, 1034 e-mail: zrubka.zsombor@uni-obuda.hu)

A cikk a Creative Commons Attribution 4.0 International License (https://creativecommons.org/licenses/by/4.0/) feltételei szerint publikált Open Access közlemény. (SID_1) 